\title{
Capture techniques' use of Caranguejo-uçá crabs (Ucides cordatus) in Paraíba state (northeastern Brazil) and its socio-environmental implications
}

\author{
DOUGLAS M. NASCIMENTO ${ }^{1}$, EMMANOELA N. FERREIRA ${ }^{1}$, DANDARA M.M.S.Q. BEZERRA ${ }^{1}$, \\ POLLYANA D. ROCHA ${ }^{2}$, RÔMULO R.N. ALVES ${ }^{2}$ and JOSÉ S. MOURÃO ${ }^{2}$ \\ ${ }^{1}$ Departamento de Sistemática e Ecologia, Universidade Federal da Paraíba, \\ Rua José Serrano Navarro, s/n, Cidade Universitária, Castelo Branco, 58051-900 João Pessoa, PB, Brasil \\ ${ }^{2}$ Departamento de Biologia, Universidade Estadual da Paraíba, \\ Av. Baraúnas, 351, Campos Universitário, Bodocongó, 58109-753 Campina Grande, PB, Brasil
}

Manuscript received on October 3, 2011; accepted for publication on November 24, 2011

\begin{abstract}
The present study was undertaken in two traditional communities that are located on the margins of the estuary and mangrove complex of the Mamanguape River, Paraíba state (PB), Brazil. This work describes the crabs capture techniques tapamento and redinha, and identifies the negative socio-environmental impacts of redinha, using qualitative methods (open and semi-structured interviews, guided tours, direct observation and the administration of questionnaires). Results indicate that currently only two principle techniques are used to capture Ucides cordatus: redinha and tapamento. Tapamento has a low impact in relation to redinha. Redinha was pointed out by interviewees as a system that has social impact (social conflicts, breaking of traditions, substitution and extinction of techniques) and environmental impact (less selective captures and high productivity, mangrove pollution, death of crabs caught in traps, cutting of the roots of Rhizophora mangle, micro-habitat loss resulting from galleries destroyed and polluted). Knowledge of crab harvesting carried out using these two techniques and the possible social and environmental impacts caused by redinha, can lead to more effective planning and actions towards the conservation of the species.
\end{abstract}

Key words: crab catchers, harvesting techniques, mangrove, traditional knowledge.

\section{INTRODUCTION}

Mangroves are coastal ecosystems found in tropical and subtropical zones, and they feature intrinsic and complex mixtures of ecological and socioeconomic aspects. The biological importance of mangroves undoubtedly resides in the fact that many plants, invertebrates (crustacean, molluscan and others) and vertebrate species use these ecosystems as breeding and living areas during part or all of their

Correspondence to: Douglas Macêdo do Nascimento e-mail: douglasmacedo84@gmail.com life cycles (Hatcher et al. 1989, Robertson et al. 1992, Twilley et al. 1996). The fauna and flora of mangroves constitute an intricate food web that is essential to the health of coastal ecosystems, as well as to the adjacent sea (Schaeffer-Novelli 1995). These ecosystems are also used by large numbers of subsistence fishermen (Odum and Heald 1972).

Brazil has 8,500 km of coastline and the second largest area of continuous mangroves on earth (Kjerfve et al. 1997). Mangrove forests provide many economically important resources such as timber, 
medicinal products, natural dyes, fish, crustaceans, and mollusks (Alves and Nishida 2002, 2003, Mourão and Nordi 2002a, b, Alves et al. 2005, Mourão and Nordi 2006; Nishida et al. 2006a; Rocha et al. 2008; Nordi et al. 2009). Brachyura crabs are a major economic resource for coastal human populations in northeast Brazil, and the main species harvested are goiamum (Cardisoma guanhumi), siris (Callinectes spp.), and the caranguejo-uçá (U. cordatus). U. cordatus is the species most heavily exploited by people living in mangrove areas in the state of Paraíba (Alves and Nishida 2002, 2003, Alves et al. 2005, Nishida et al. 2006b, N. Nordi, unpublished data), and studies of management and economic sustainability in Brazilian mangrove areas have suggested that traditional harvesting of crustaceans (most notably the $U$. cordatus) is the most profitable activity for local human populations (Kjerfve and Lacerda 1993, IBAMA 1995).

Many coastal communities in Brazil (and throughout the world) depend on mangrove ecosystems for their subsistence, whether in the form of fish, wood extraction, or tourism (T.L.P. Dias, unpublished data), but these mangroves are relatively fragile ecosystems and require reasonable care if their riches are not to be depleted (Vannucci 1999). Special attention must be given to technologically innovative harvesting techniques, as they make production more efficient and require less physical effort to exploit a given natural resource (Botelho et al. 2000). Increased harvesting (combined with lower selectivity in relation to traditional techniques) can exceed the replacement limits of a given resource, leading to the degradation of the population structure, and will consequently threaten the survival of traditional communities that depend on these resources.

One of the major activities carried out in mangrove ecosystems in Brazil is the harvesting of $U$. cordatus. Many crab catchers (caranguejeiros) depend almost exclusively on the capture and sale of this resource for their sustenance during most of the year(N. Nordi, unpublished data), and this activity is of significant economic importance in the Mamanguape
River Estuary (MRE) (Paludo and Klonowski 1999). Various techniques are used in Brazil to capture $U$. cordatus, including: harvesting by braceamento, tapamento, ratoeira, redinha, raminho (Alves et al. 2005, N. Nordi, unpublished data), pé (Nunes and Samain 2004), laço (Maneschy 1993), and gancho or cambito. Among these techniques, the ratoeira, laço, and redinha are examples of innovative technologies. Redinha is considered highly predatory on crab resources (Maneschy 1993, Botelho et al. 2000, Alves and Nishida 2003, Nunes and Samain 2004, M.M.L. Leite, unpublished data).

The redinha technique has been implicated in various negative impacts on mangrove ecosystems and specifically on $U$. cordatus. As such, the present study examined the capture process using the redinha and tapamento techniques and also identified the socio-environmental impacts produced by the redinha technique based on the view of two communities. The decision to study these techniques is justified by the fact that they are the ones currently used in the estuary for capturing $U$. cordatus and also because one is considered predatory (redinha) and the other of low impact (tapamento). This research was designed to provide qualitative information that could be useful in future quantitative studies on the currently known impacts, and in the investigation of those still not yet identified and proven by scientific literature, highlighted the ones caused by redinha. Contributions in this area will lead to a better understanding of the problematic issues and to the establishment of regulations and management plans to govern the harvesting of these crabs and to help guarantee the sustainability of this resource and the preservation of the local culture.

\section{MATERIALS AND METHODS}

THE STUDY AREA

The Mamanguape River Estuary (MRE) covers 16,400 ha. $\left(06^{\circ} 43^{\prime} 02^{\prime \prime}\right.$ to $06^{\circ} 51^{\prime}$ '54' $\mathrm{S}$ and $35^{\circ} 07^{\prime}$ $46^{\prime \prime}$ to $34^{\circ} 54^{\prime} 04^{\prime \prime} \mathrm{W}$ ) (Fig. 01 Aand B) and is situated 
within the Environmental Protection Area (APA, from Portuguese), in Barra do Rio Mamanguape, Paraíba state, Brazil. The estuary comprises a large mangrove area (5,400 ha.), camboas (arms of the main river that cuts through the mangrove), croas (sand/mud river banks), apicuns (areas without typical mangrove vegetation) and a barrier reef perpendicular to the mouth of estuary.
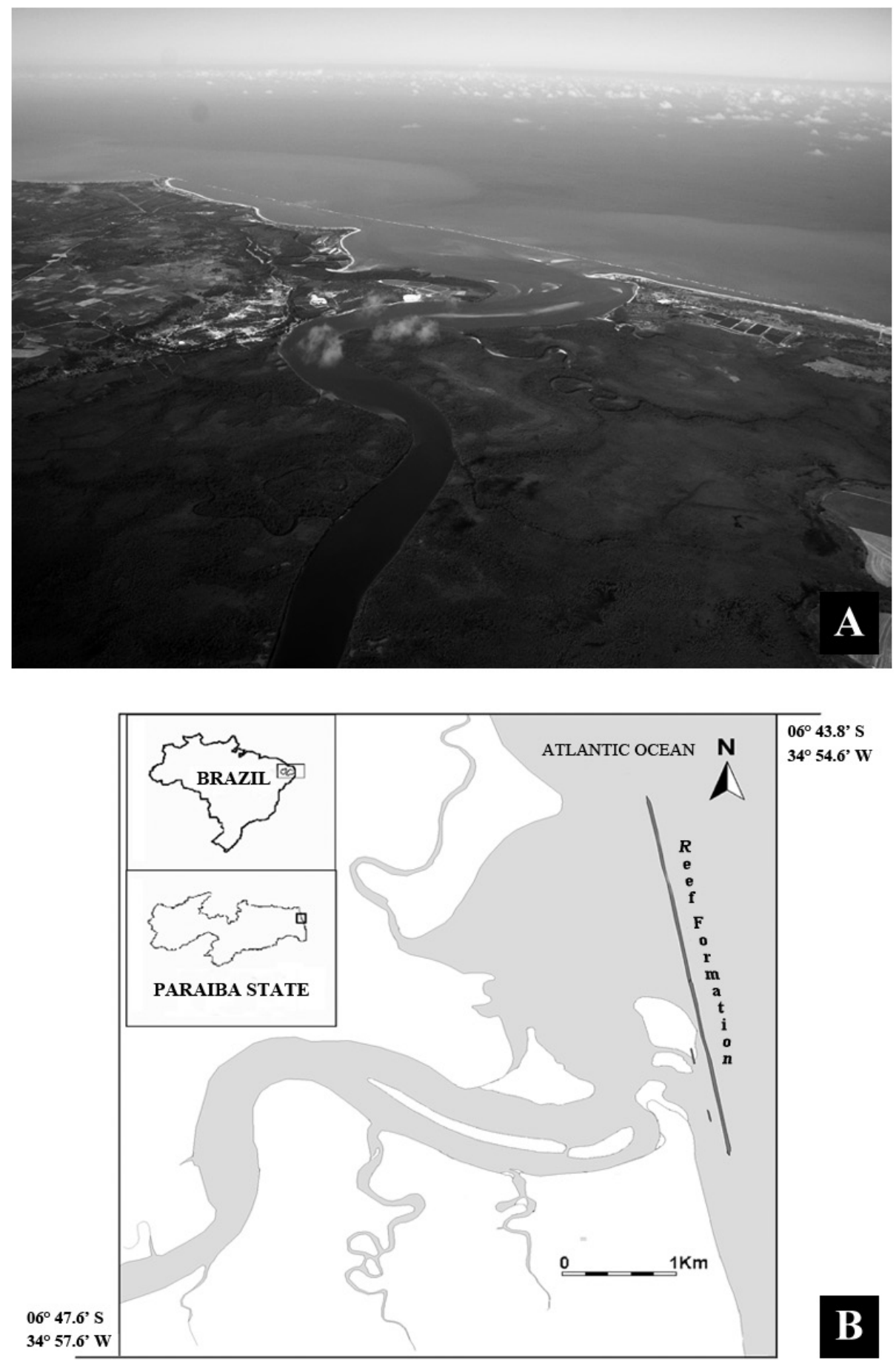

Figure 1 - River Mamanguape Estuary. A: Aerial view; B: georeferenced map. (Figure adapted from Xavier et al. 2012). (Photo - A: Dirceu Tortorello 2008). 
The communities of Tramataia and Três Rios (in the municipality of Marcação) consulted in the present research are poor villages populated by a mixture of Potiguara Amerindians, African, and European descendents who practice extractivist activities in the MRE (Mourão and Nordi 2003). Various shellfish are extracted from the mangrove-estuary complex, such as molluscs (Anomalocardia brasiliana, Crassostrea brasiliana and Mytella sp.), and crustaceans ( $U$. cordatus, C. guanhumi, Goniopsis cruentata, Callinectes spp., Pennaeus subtilis and Pennaeus schmitti), besides several fish species. However, the most important economic activity performed by the communities living near the estuary of Mamanguape river is the capture of $U$. cordatus (Paludo and Klonowski 1999). These communities have a very close relationships with the mangroves as it represents their only source of subsistence, and while the region is very rich in natural resources these populations remain very poor and suffer from deficiencies in terms of medical care, education, and public sanitation (J.S. Mourão, unpublished data). The specific study group was composed of $U$. cordatus harvesters, locally known as caranguejeiros.

\section{PROCEDURES}

Field work was carried out during the period between January and July, 2007, with two visits being made every month. Research was divided into two basic stages. In the first research stage (January and February, 2007) surveys were made to select informants. Visits were made to establish mutual confidence between the researcher and the interviewee (Costa-Neto and Marques 2000, S.C.S. Montenegro, unpublished data) before the open interviews were held and to help define the profile of the target population.

The second stage of the project was undertaken between March and July, 2007, using the following techniques: open and semi-structured interviews, guided tours, direct observation and the application of questionnaires about harvesting activities.
The interviews first proceeded as open or free, where the respondents willingly discussed the proposed theme and spoke freely on their lifestyle, becoming structured as particular issues were addressed (S.C.S. Montenegro, unpublished data).

Semi-structured interviews (formulated questions but with free answers on the proposed theme) were held with a total of 21 community members, including $17 \mathrm{crab}$ catchers, 3 former crab catchers, and the president of the Tramataia fishery colony, comprising questions on general aspects about the capture procedure and specific issues such as the use of redinha. The individuals were selected by the "native specialists" criterion, meaning people self-recognized and accepted by the community as culturally competent (J.G.W. Marques, unpublished data). In the communities studied, the activity is exclusively men's work. The interviews were recorded on an MP3 device, always preceded by the interviewer's identification with a concise explanation about the purpose of the study and a request for permission to record him, adding up a total of 8.5 hours of dialogue (that was subsequently transcribed).

We employed the techniques of data control through interviews in synchronous situations (with the same questions being placed to different people in the same time interval) as well as in diachronic intervals to assure the validity of the information registered (the same question was placed to the same person at widely spaced time intervals of three months).

The techniques of direct observation and guided tours consisted of collecting excursions to the mangrove in the company of crab catchers. For each technique, two direct observations and a guided tour were conducted at the work of a crab gatherer, selected based on his extensive experience in the field. Initially, the direct observation took place in order to survey the entire capture process, causing minimal interference, which included descriptions of these techniques, strategies and environmental 
impacts as well. In guided tours, the crab gatherer explained the functioning of the techniques, and questions about the process were answered.

\section{RESULTS AND DISCUSSION}

DESCRIPTIONS OF THE HARVESTING TECHNIQUES

\section{The redinha technique}

Interviews and field excursions indicated that two harvesting techniques are currently being used by the crab catchers in the study communities: the redinha and tapamento. The redinha technique is


Figure 2 - Description of the redinha technique. A: Redinha fixed to the opening of a caranguejo-uçá crab burrow in the MRE mangrove; B: Crab caught in a redinha in the MRE mangrove. (Photo - A, B: José Mourão 2007). composed by four phases: 1) the crab catcher will dig away at the mouth of the crab burrow (toca) with a machete to increase its diameter so that a small net/snare (redinha) can cover the opening; 2) cut off a short section of a prop-root from a mangrove tree (Rhizophora mangle) and divide it into two or more pieces to secure the nylon strings of the snare (redinha), and then push them further into the burrow (Fig. $02 \mathrm{~A}$ ); 3) wait for two or three hours for the crab to become ensnared (Fig. 02 B); and 4) return to catch the animals in a "trap-line" procedure.

To facilitate finding the burrows where the redinha were placed, three techniques are used: (1) very often the crab catcher tracks can be seen in the muddy sediment and easily followed; (2) the brightly-colored redinha can usually be seen at the open of the burrow; and (3) when working in groups, the catchers will mark one of the prop-roots of a nearby $R$. mangle tree by cut off some of the bark with a machete so it can be seen more easily (Fig. 03 A).

The redinha technique was probably invented in Brazil at the start of the 80's in Rio de Janeiro (Nunes and Samain 2004). According to the former crab catcher José Mendes (61 years-old), the redinha technique was introduced in the MRE in the same decade: "It came from Rio de Janeiro". However, the Brazilian Environmental Agency (IBAMA from Portuguese) has officially prohibited the use of this catch technique in Brazil, for the northern and northeastern (Regulation \# 034/03-N), and southeast and south regions (Regulation \# 52/2003).

The majority of works published about the redinha describes this technique superficially, without more details. Nunes and Samain (2004) studied crab catchers working in mangroves at Vitória (ES), while Botelho et al. (2000) describes the use of this artifact in the Rio Formoso estuary (PE) with reasonable detail. The descriptions of the redinhas's use and installation are similar to those by Botelho et al. (2000), but differ in relation to Nunes and Samain (2004) description. The use of branches 

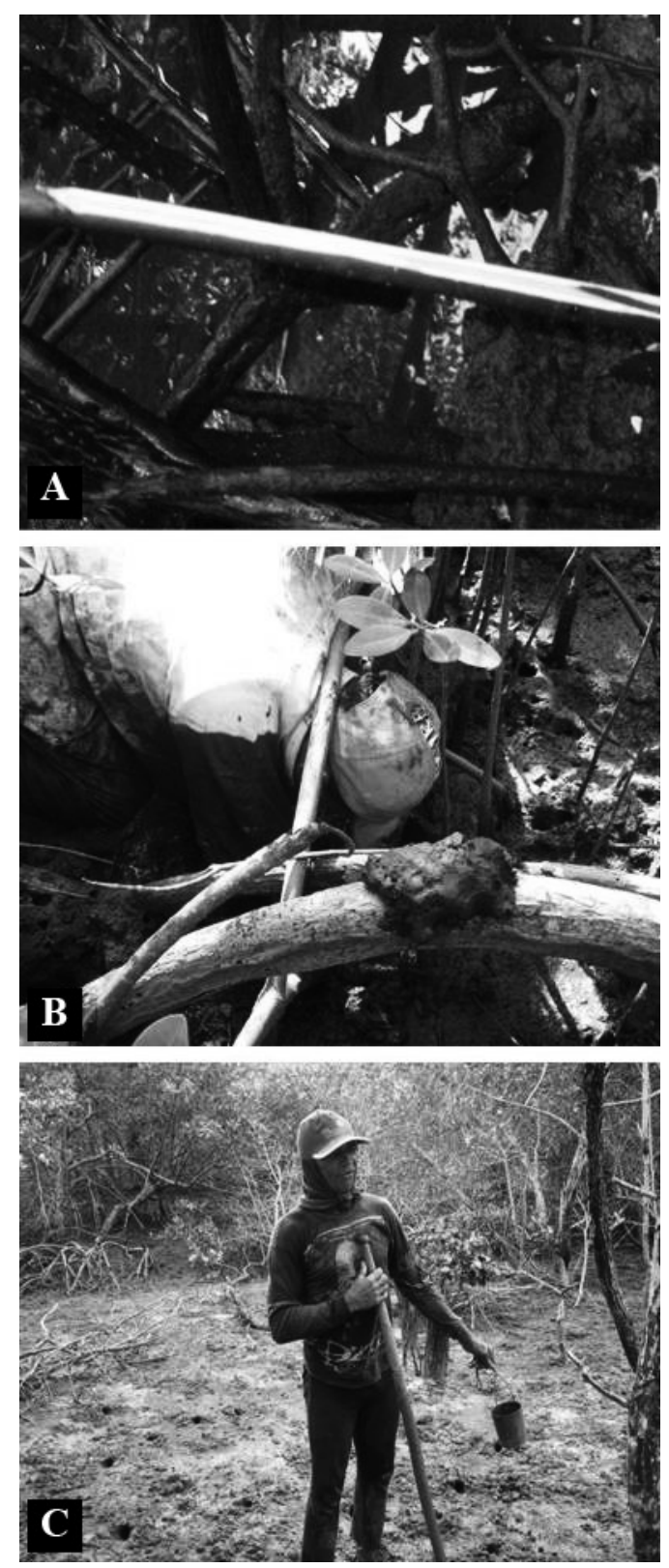

Figure 3 - Capture strategies. A: Root of Rhizophora mangle marked by a crab gatherer to facilitate locating crab burrows in the MRE mangrove; B: A small mound of mud sediment placed on a prop root of a mangue sapateiro tree ( $R$. mangle) in the MRE mangrove to mark the location of a crab burrow; $\mathbf{C}$ : Crab gatherer holding a boi de fogo smudge pot in his left hand while working in the MRE mangrove. (Photos - A, B, C: José Mourão 2007).

or tree trunks are used to hold the snares in the region of Vitória (ES), while N. Nordi (unpublished data) reported the use of two tree branches for the same purpose in Várzea Nova (PB).

\section{The tapam ento technique}

The tapamento technique proceeds in two stages: 1) the crab catcher widens the crab burrow's opening with a tool called ferro de córvo (a steel blade attached to a wooden handle) (Fig. 04 A and B) and then close it with mud and mangrove sediments by pushing them into the burrow with his feet with practiced force (Fig. 04 C); and 2) involves the capture of the crabs after a certain period of time. According to the crab catchers, the animals that were trapped in their burrows will eventually dig themselves out, but being worn out by the effort and by the lack of oxygen they become easy prey: "When he starts climbing out, he has to climb up, and I've closed off his escape, if I don't close off the exit he comes up and goes back in. If he came up and got a good breath, he won't worry about coming up again". Accordingly, the crab catchers will return to the burrow and dig it out to capture the crab manually (braceamento) (Fig. 04 D) and store it in a polypropylene sack.

In order to locate the closed burrows, the crab catchers will follow their own tracks back. During the rainy season, or when the tide comes in, the crab harvesters will leave a mound of mud on an aerial root near the burrow (Fig. 03 B) or, less frequently, they will stick pieces of severed roots into the ground at the site.

The survey made at the MRE demonstrated that the procedures used to capture U. cordatus are similar to that employed by crab catchers in Várzea Nova, PB, as studied by N. Nordi (unpublished data). The tapamento technique (a variation of the braceamento technique) was described similarly by N. Nordi (unpublished data). In the braceamento technique, the crab catcher inserts his arm into the burrow, grasps the crab by its dorsal carapace, pressing its chelae with his thumb and index finger, immobilizing them against the palm of his hand, pulling out the crab laterally. The main advantages of this technique are (a) crab catchers do not follow a pre-defined route, and are consequently able to cover a larger foraging 

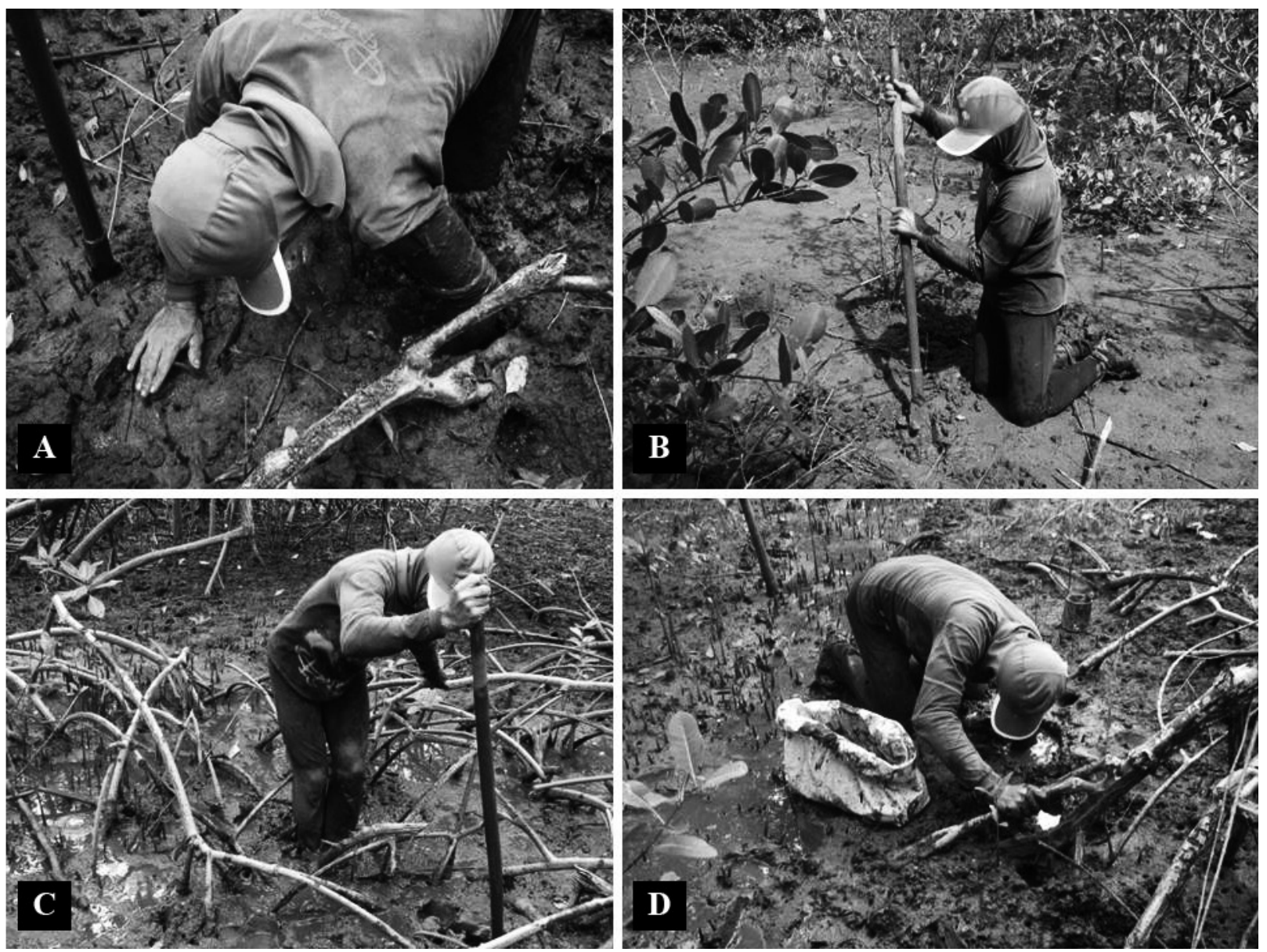

Figure 4 - Description of the "tapamento" technique. A: Crab gatherer increasing the diameter of the crab burrow with his hands in the MRE mangrove; B: Crab gatherer using a ferro de córvo digging tool in the MRE mangrove. C: Crab gatherer obstructing the burrow of a caranguejouçá crab in the MRE mangrove. D: Crab gatherer utilizing the braceamento technique to remove a caranguejo-uçá crab from its burrow during the catação stage, in the MRE mangrove. (Photo - A, B, C, D: José Mourão 2007).

area than tapamento catchers; and (b) they do not have to revisit burrows (Nordi et al. 2009).

Botelho et al. (2000) recognized redinha technique as a recent technological innovation of the crab catchers. Catchers who utilize tapamento are called "true crab fishers" because this method requires greater knowledge of both the $U$. cordatus and their environment ( $\mathrm{N}$ Nordi, unpublished data). This author stated that tapamento was the predominant technique among the indigenous population for centuries, and that although this technique is less efficient, it is apparently more elaborate, less predatory, more selective and less dangerous than the redinha technique. This latter characteristic (associated with the greater commercial value of the crabs harvested by tapamento) appears to be the principal reason for the persistence of this harvesting style. Accordingly, as pointed out by Alves and Nishida (2003), the use of the redinha technique indicates a clear rupture with traditional harvesting, as the new technique requires less physical effort from the collector than in tapamento. The introduction of this new technology has clear conservation implications, for although this practice is considered predatory and is legally prohibited, it is still widely used. 
Socio-environmental impacts produced by the redinh technique

Research that addresses the impacts of this technique stresses basically three, all environmental: pollution from nylon threads, less selective capture and cutting of the roots of Rhizophora mangle. However, in the Mamanguape River estuary, environmental and social impacts were still not evident.

TABLE I

Socio-environmental impacts produced by the redinha technique in the MRE mangrove.

\begin{tabular}{|c|c|}
\hline $\begin{array}{c}\text { ENVIRONMENTAL } \\
\text { IMPACTS }\end{array}$ & SOCIAL IMPACTS \\
\hline Mangrove's pollution & Social conflicts \\
\hline Captured crabs death redinhas & Departure from local traditions \\
\hline $\begin{array}{c}\text { Cutting the roots of the } \\
\text { mangle }\end{array}$ & $\begin{array}{c}\text { Substitution of harvesting } \\
\text { techniques }\end{array}$ \\
\hline Loss of micro-habitats & $\begin{array}{c}\text { Extinction of harvesting } \\
\text { techniques }\end{array}$ \\
\hline Less selective harvesting & \\
\hline Exaggerated harvests & \\
\hline
\end{tabular}

Table I lists the socio-environmental impacts caused by the utilization of the redinha snare, according to the crab catchers $(n=21)$. Some of these items were observed and photographed in loco.

\section{Environmental impacts}

Crabs entangled in the redinha snares may die if left and forgotten by the crab catchers (Fig. 05 A). Intact but empty snares from one day's trapping are often left in place and removed in subsequent days; if the collectors forget them, however, any trapped crab will die in a few days or will be preyed by animals such as raccoons (Procyon cancrivorus), it does not happen always.

Cutting the prop roots of the mangue sapateiro tree ( $R$. mangle) appears to be one of the most serious impacts felt by the mangrove ecosystem (Fig. 05 B). "... the bad part of the redinha is that the mangrove gets cut up, they cut the roots of the mangue a lot" (about the harvesters who use the redinha snare). For every redinha snare placed in a burrow, at least one root is cut. On the average, 180 redinhas are set out by each crab catchers during each work day - signifying that 180 roots are cut by every collector. Considering that most harvesters (70\%) work the mangrove five times during the week, a total of 49,680 roots would be cut by a single worker in one year.

The polypropylene material used to make the snares is usually simply discarded by the crab catchers when no longer useful, and remains to pollute the mangrove (Fig. $05 \mathrm{C}$ ). Other types of pollution can also be cited, such as the rotting of
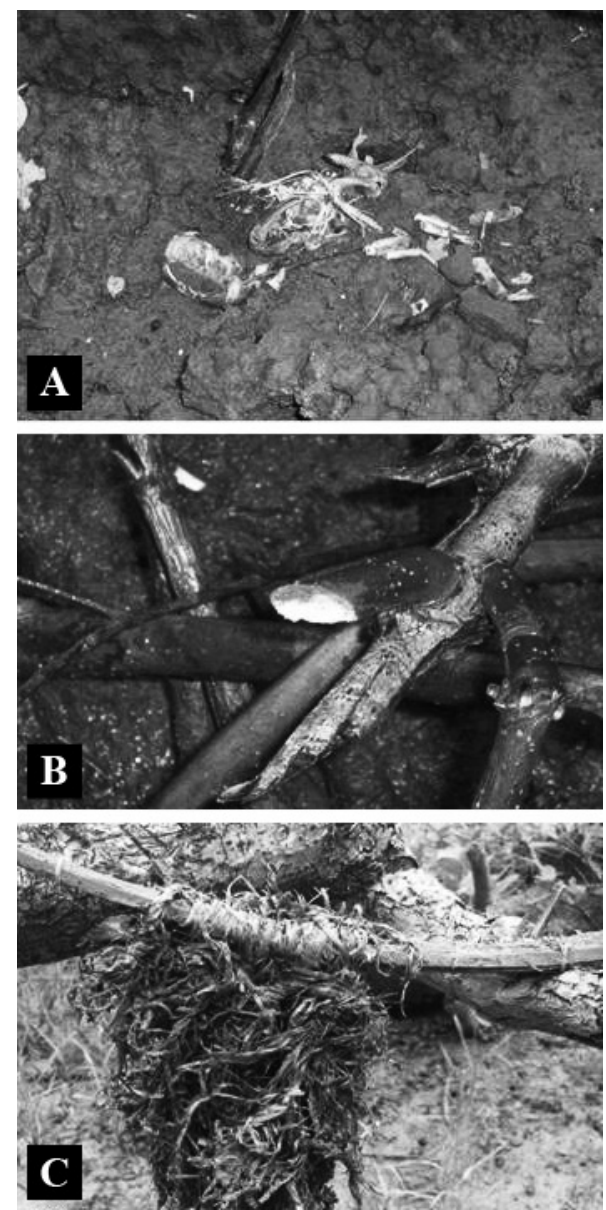

Figure 5 - Environmental impacts. A: Remains of a dead crab ensnarled in a "redinha" left in the MRE mangrove; B: Cutting a root prop of the mangue sapateiro tree ( $R$. mangle) with a machete in the MRE mangrove; $\mathbf{C}$ : Redinhas thrown away and/or forgotten by crab gatherers in the MRE mangrove. (Photo-A, B, C: José Mourão 2007). 
the severed roots and the decomposition of the dead crabs ensnared in the redinhas that are forgotten in the mangrove. According to the crab catchers themselves, this type of pollution tends to drive off the crabs as these animals are alleged to be very selective about environmental conditions: "The caranguejo-uçáu crab is clean. They are clean" (a retired crab gatherer from Três Rios).

Some crab catchers (14.2\%) also pointed out that the intensive use of the redinha snare results in the loss of micro-habitats (the crab dens), due to their destruction, and pollution, thus impairing the survival of the goby (Bathygobius soporator) and siris blue-crabs (Callinectes exasperatus), which can also inhabit the empty burrows, mainly to hide from predators. “... the gobies stayed there, the bluecrabs stayed there, but nowadays nothing lives in the burrow of the crabs caught in the redinha" (a crab gatherer from Tramataia). Consequently, the harvests of gobies and blue-crabs are also affected by this snaring technique, although it is not known how much. This information relies solely on the observations made by crab catchers who eventually capture these animals, and as a capture strategy, they search the $U$. cordatus burrows. According to them, to catch these resources in impacted areas by the use of redinha, mainly the goby, is considered difficult.

According to the interviewees, poorly selective crab capture is due to the inexperience of many new crab catchers, to the increasing number of collectors, the decrease in the quantities and sizes of the crabs, and the pressure exerted by the middlemen (who buy the small crabs and females just for the meat they can extract). "So, the guy who uses a redinha, he's not choosing the size of the crab, no. So if it's a female, he's not going to take it? Everything goes." (a crab gatherer from Três Rios). Despite the claims made by several authors, including IBAMA, which indicate a low selectivity, no quantitative and comparative study has been conducted.

According to the crab catchers, the enhanced productivity of the redinha technique is derived from the ease in handling these snares (allowing each collector to set an average of 180 traps per day), and from the efficiency of their capture. This same relationship was noted by Nunes and Samain (2004), who reported that the use of redinha snares provided a much greater productivity in relation to traditional techniques. However, such statement is not supported by quantitative and comparative data.

Our data agrees with the results obtained by previous authors, who have shown impacts associated to the redinha technique. Nunes and Samain (2004) identified two principal environmental impacts resulting from the use of the redinha in the mangroves of Vitória, Espírito Santo state, Brazil: the mortality of the forgotten crabs entangled in the redinhas, and their non-selective capture. Botelho et al. (2000) stated that the use of the redinha snare along the southern coast of Pernambuco state, Brazil, is impacting the mangrove, principally because of the continuous cutting of the roots of $R$. mangle in order to secure the snares - at the rate of 42,000 linear meters of prop roots per year. Other problems include visual pollution caused by the nylon waste and the low selectivity of the capture. A.J. Schmidt et al. (unpublished data) reported that the mangroves in Vitória, Espírito Santo, have experienced heavy anthropogenic pressure due to the predatory harvesting of the $U$. cordatus using the redinha technique - specifically citing the fact that both males and females were being indiscriminately snared. In their study of the mangroves in Iguape, São Paulo state, Pinheiro and Fiscarelli (2001) estimated that $36,000 \mathrm{crabs} / \mathrm{month}$ were capture by the redinha method, a number that may be sufficient to threaten the natural stock of these animals (Fiscarelli and Pinheiro 2002). The crab catchers working these mangroves at Iguape, do in fact point to the redinha technique and the excessive numbers of collectors in the mangrove as being the main causes of the diminishing yields of crabs (Fiscarelli and Pinheiro 2002). Nunes and Samain (2004) stress that the introduction of the redinha technique 
initiated a significant change in the quantity and quality of crabs captured in Vitória, Espírito Santo. Production increased significantly in relation to traditional techniques, and favoring an increase in the number of people harvesting the crabs as well. In spite of evidence of decreased stocks of $U$. cordatus related to the use of redinha, none of these studies have sufficient basis to prove it.

\section{Social impacts}

Within the communities studied, social conflicts were noted based on disagreements between the crab catchers that utilize the tapamento technique and those that had adopted the redinha method. However, in spite of the differences about this subject (which could be perceived by the heated discussions that occurred during the interviews), any overt conflicts are apparently avoided in the communities.

The use of the redinha substituted older techniques such as the braceamento and ratoeira, and resulted in their effective extinction. Alves and Nishida (2003) surveyed the different collecting techniques used by crab catchers $(\mathrm{n}=$ 70) in four different communities (Camurupim, Jaraguá, Marcação, and Tramataia) in the MRE and discovered that $44 \%$ used the tapamento method, 43\% used tapamento and braceamento, $10 \%$ utilized the redinha, and only $3 \%$ used braceamento in that study year (2002). After seven years, a significant change was evident: of the crab catchers interviewed $(n=20)$ in two communities (Tramataia and Três Rios), $85 \%$ utilized the redinha and only $15 \%$ the tapamento technique. The ratoeira, usually employed to capture $C$. guanhumi, but also used to harvest $U$. cordatus, had fallen into disuse. Respondents also confirmed the change and that tapamento was practiced by few people in the communities studied.

The introduction of this simple but technologically more advanced device is drastically changing local traditions, as the use of the redinha modifies the entire relationship of crab catchers with the mangrove - diminishing physical contact, and with it, the social interaction. The growing numbers of users of redinha technique is slowly eroding traditional knowledge about the MRE, knowledge that involved an elaborate understanding of the mangrove ecosystem as a whole. The knowledge of tapamento is not being passed on to the next generation, making it all the more important described and recorded here. A similar trend has been observed by Nunes and Samain (2004) in Vitória, ES, Brazil, where this technique put traditional crab harvesters at a great disadvantage in relation to the redinha collectors due to the ease and efficiency of its use.

Although it is not directly related to the use of redinha, another social conflict that should be mentioned is the uneasy relationship between the crab catchers and the IBAMA. The repressive nature of the officials working with IBAMA, the lack of dialog, information, and explanations in relation to harvesting prohibitions of $U$. cordatus, and events such as the mass mortality of the crab caused by lethargic crab disease (LCD), have greatly strained their relationship. Alves and Nishida (2002) reported that the mortality mentioned by collectors occurred in 1998 in the mangroves of Paraíba, resulting in an $84 \%$ reduction of the outstanding natural Ucides cordatus stock, creating social problems and seriously affecting the economic situation of the poor population that depended on this resource. Fiscarelli and Pinheiro (2002) reported that in spite of efforts made by the regulating agencies, verbal communication is still the most common form of passing information concerning laws that determine the closed seasons for harvesting $U$. cordatus in the mangroves at Iguape, São Paulo state, resulting in the fact that $41.7 \%$ of the crab catchers still do not know the closed-season dates.

\section{FINAL CONSIDERATIONS}

This study, along with others such as Passos and Di Beneditto (2005), Jankowsky et al. (2006) and 
Castilho et al. (2008) have demonstrated that the redinha technique has been substituting traditional harvesting techniques in spite of legal prohibitions imposed by environmental agencies. Due to the easy use and high production of the redinha technique it has rapidly spread through most crab-harvester communities and thus intensified the collection pressure focused on $U$. cordatus. Traditional tapadores represent the most specialized group of harvesters, as their technique is more elaborate and its users must have a refined sense of the functioning of the ecosystem. The form in which this harvesting technique is used reflects the close relationship that the crab catchers have with the mangrove. The fact that redinha is a less elaborate technique than tapamento, does not imply that the crab catchers who use it are not very knowledgeable about the mangrove ecosystem. Regardless the technique, it is imperative to understand biotic (the animal bioecology, for instance) and abiotic (tidal and sediment types, for instance) factors for successful harvesting, besides an accurate sense of direction to get around. Moreover, most collectors who use redinha in the Mamanguape River estuary previously used traditional techniques, particularly tapamento.

The evident change of traditional techniques toward redinha is related to the facilities it provides to increase production, and consequently to improve the lives of the crab catchers. According to the views of those who use it, the application of redinha brings about some sort of impact, but it is not significant enough to indicate environmental degradation and consequent decrease in the crab stock. We also noticed a clear concern of these crab catchers for the conservation of resources in the MRE.

The prohibition of the redinha technique use for the whole country does not take into account local realities and quantitative information to ensure that the technique is predatory. If this information exists, it is not published, which leads to the need for deeper studies on the topic since this activity is usually the only means of survival for crab catchers.
The traditional capture of $U$. cordatus requires a detailed knowledge of the mangrove environment and gives local populations a better understanding of the role of human interactions with this ecosystem. As was pointed out by Alves et al. (2005), traditional crab harvesters have a profound knowledge of $U$. cordatus and have demonstrated a continuing concern with the preservation of that species, as they depend directly on that natural resource to guarantee their survival.

In light of the high rate of unemployment common in Brazil, mangroves have offered many people an alternative source of income, thus increasing harvesting pressure on the most economically important natural resources available, such as $U$. cordatus (Alves and Nishida 2003). These new catadores are not proficient in the techniques used by traditional harvesters, and in seeking more results with less physical effort they have introduced new and more predatory capture techniques such as the redinha, stated the crab catchers. In addition to the environmental problems associated with the redinha, the introduction of this new technology contributed to cultural erosion of traditional local harvesting techniques (and all of their associated knowledge) as the next generation of crab hunters no longer needs to acquire that information to be successful in there collecting.

The introduction of predatory techniques associated with the lack of public policies directed towards environmental management resulted in a very strong pressure on Ucides cordatus in the Mamanguape River estuary. The indiscriminant use of the redinha, together with the increasing numbers of harvesters and the ease of capturing and marketing the crabs, may maximize the harvest pressure and will most certainly alter the population structure of $U$. cordatus, if no conservation measures are taken by the environmental agencies in Brazil. It is also important to consider several other factors (in addition to exploitation through 
human harvesting) that have contributed to reduce natural populations of $U$. cordatus. In Brazil, like in many other tropical countries, mangrove forests have been widely cleared through anthropogenic activities. Studies focused on these ecosystems as well as the animals highly dependent on them are important to establish programs for their effective and sustainable management (Bacon and Alleng 1992, Farnsworth and Ellison 1997). Studies with careful attention to the ecology of human resource use are especially critical in light of the widespread influence of humans on mangrove ecosystems (Walters 2005, Walters et al. 2008).

Understanding how and why humans use forest and aquatic resources within the mangrove, and how these use-patterns impact this ecosystem is vital for effective management, yet such information is rarely available for planning and policy discussions. Standardised collections of this type of information from local communities is a necessary first step in assuring that policies and laws are anchored in the local environmental and socio-economic reality (e.g., Kaplowitz 2001, Omodei-Zorini et al. 2004, Walters 2004, Dahdouh-Guebas 2006, Rist and Dahdouh-Guebas 2006).

The regulation of crab capture is the responsibility of the IBAMA, but a conservationoriented regulatory framework currently in effect is based on prohibitive rules that were largely designed without the participation of the crab collectors themselves.

The implementation of a successful management strategy requires the involvement of the main stakeholders, and they must be made aware of the necessity of conserving natural resources to guarantee their own survival. It is therefore wise to use their accumulated traditional knowledge together with an evaluation of their socio-economic conditions in formulating laws and management plans that can efficiently regulate crab harvesting in the Mamanguape Environmental Protection Area.

\section{ACKNOWLEDGMENTS}

The authors would like to thank the residents of Tramataia and Três Rios, especially the crab catchers and former catchers who kindly shared their valuable knowledge with us; Gleide Maria Fernandes for her hospitality in Baía da Traíção, PB; and Conselho Nacional de Desenvolvimento Científico e Tecnológico (CNPq) for financial support and travel expenses; the Barra do Mamanguape River Environmental Protection Area (APA) for housing in Barra de Mamanguape, PB.

\section{RESUMO}

O estudo foi realizado em duas comunidades tradicionais localizadas às margens do complexo estuário-manguezal do rio Mamanguape, Paraíba (PB), Brasil. Foram descritas as técnicas de captura (tapamento e redinha), identificando os impactos socioambientais negativos provocados pela redinha na captura de caranguejos, utilizando métodos qualitativos (entrevistas abertas e semiestruturadas, turnês guiadas, observação direta e questionários). Os resultados indicaram que atualmente apenas estas técnicas são usadas na captura de Ucides cordatus. O tapamento apresenta baixo impacto em relação à redinha, que é apontada pelos entrevistados como causadora de impactos sociais (conflitos sociais, rompimento de tradições, substituição e extinção de técnicas) e ambientais (captura menos seletiva e grande produtividade, poluição do manguezal, morte dos caranguejos presos às armadilhas, corte das raízes de Rhizophora mangle, perda de micro-habitat resultante das galerias destruídas e poluídas). O melhor conhecimento sobre a captura de caranguejos por tais técnicas, bem como seus possíveis impactos socioambientais, podem aumentar a eficiência de planejamento e ações voltados à conservação da espécie.

Palavras-chave: caranguejeiros, técnicas de captura, manguezal, conhecimento tradicional.

\section{REFERENCES}

ALVES RRN AND NISHIDA AK. 2002. A ecdise do caranguejouçá, Ucides cordatus (Crustacea, Decapoda, Brachyura) na visão dos caranguejeiros. Interciencia 27: 110-117. 
ALVES RRN AND NISHIDA AK. 2003. Aspectos socioeconômicos e percepção ambiental dos catadores de caranguejo-uçá Ucides cordatus cordatus (L. 1763) (Decapoda, Brachyura) do estuário do rio Mamanguape, Nordeste do Brasil. Interciencia 28: 36-43.

Alves RRN, NishidA AK AND HeRnANDEZ MIM. 2005. Environmental Perception of Gatherers of the Crab Caranguejo-uçá (Ucides cordatus, Decapoda, Brachyura) Affecting Their Collection Attitudes. J Ethnobiol Ethnomed 1: 1-8.

BACON PR AND ALLENG GP. 1992. The management of insular Caribbean mangroves in relation to site location and community type. In: JACCARINI V and MARTENS E (Eds), The ecology of mangrove and related ecosystems. Kluwer Academic Publishers, Netherlands, p. 235-241.

Botelho ERO, SANTOS MC AND PonTES ACP. 2000. Algumas considerações sobre o uso da redinha na captura do caranguejo-uçá, Ucides cordatus (Linnaeus, 1763), no litoral sul de Pernambuco - Brasil. Bol Téc Cient CEPENE 8: 55-71.

Castilho GG, Ostrensky A, Pie M and Boeger W. 2008. Estado da arte das pesquisas com o caranguejo-uçá, Ucides cordatus. AVS 13: 151-166.

CostA-Neto EM AND MARQUES JGW. 2000. A etnotaxonomia de recursos ictiofaunísticos pelos pescadores da comunidade de Siribinha, norte do estado da Bahia, Brasil. Biociencias 8: 61-76.

DahdouH-Guebas F. 2006. Mangrove forests and tsunami protection. McGraw-Hill Yearbook of Science \& Technology. McGraw-Hill Professional, p. 187-191.

FARNSWORTH EJ AND ELLISON AM. 1997. Global patterns of pre-dispersal propagule predation in mangrove forests. Biotropica 29: 318-330.

Fiscarelli AG AND PINHeIro MAA. 2002. Perfil sócioeconômico e conhecimento etnoecológico do catador de caranguejo-uçá, Ucides cordatus (LINNAEUS, 1763), nos manguezais de Iguape $\left(24^{\circ} 41^{\prime} \mathrm{S}\right)$, SP, BRASIL. Actual Biol 24: 129-142.

HATChER BG, JOHANNES RE AND ROBERTSON AI. 1989. Review of research relevant to conservation of shallow tropical marine ecosystems. Oceanogr Mar Biol Annu Rev 27: 337-414.

IBAMA - Instituto BRAsileiro do Meio Ambiente E RECURSOS NATURAIS RENOVÁvEIS. 1995. Os ecossistemas brasileiros e os principais macrovetores de desenvolvimento: subsídios ao planejamento da gestão ambiental. Ministério do Meio Ambiente, Recursos Hídricos e da Amazônia Legal, Programa Nacional do Meio Ambiente-PNMA. MMA, Brasília.

JANKOWSKY M, PIRES JSR AND NORDI N. 2006. Contribuições para o Manejo Participativo do caranguejo-uçá, Ucides cordatus, no município de Cananéia - SP. Bol Inst Pesca 32.

KAPLOWITZ MD. 2001. Assessing mangrove products and services at the local level: the use of focus groups and individual interviews. Landsc. Urban Plann 56: 53-60.

KJERFVE B AND LACERDA LD. 1993. Management and status of the mangroves of Brazil. In: ISME/ ITTO, Conservation and Sustainable utilization of mangrove forests in Latin America and Africa regions. Part I Latin Ameri, p. 245-272.
KJeRfVE B, LACERDA LD AND Diop ES. 1997. Mangrove Ecosystem Studies in Latin America and Africa, UNESCO, Paris, 349 p.

MANESCHY MC. 1993. Pescadores nos manguezais: estratégias técnicas e relações sociais de produção na captura de caranguejo. In: Furtado LG, Leitão W and Melo AF de (Eds), Povos das Águas: Realidade e Perspectivas na Amazônia, Museu Paraense Emílio Goeldi, Belém, Brasil, p. 19-62.

MOURÃo JS AND NORDI N. 2002a. Principais critérios utilizados por pescadores artesanais na taxonomia folk dos peixes do estuário do rio Mamanguape-Paraíba-Brasil. Interciencia 27: 607-612.

MOURÃO JS AND NORDI N. 2002b. Comparações entre as taxonomias folk e científica para os peixes do estuário do rio Mamanguape-Paraíba, Brasil. Interciencia 27: 664-675.

MOURÃo JS AND NORDI N. 2003. Etnoictiologia de pescadores artesanais do Estuário do Rio Mamanguape, Paraíba, Brasil. Bol Téc Inst Pesca, Brasil 29.

MOURÃo JS AND NORDI N. 2006. Pescadores, peixes, espaço e tempo: uma abordagem etnoecológica. Interciencia 31: 1-7.

NishidA AK, Nordi N AND Alves RRN. 2006a. Mollusk Gathers of Northeast Brazil: Gathering Techniques and Productivity. Hum Ecol 34: 133-145.

NishidA AK, Nordi N AND ALVES RRN. 2006b. Molluscs production associated to lunar-tide cycle: a case study in Paraíba State. J Ethnobiol Ethnomed 2: 1-6.

NORDI N, NisHIDA AK AND ALVES RRN. 2009. Effectiveness of two gathering tecniques for Ucides cordatus in Norheast Brazil: implications for the sustainability of mangrove ecosystems. Hum Ecol 37: 121-127.

NUNES AA AND SAMAIN E. 2004. Os argonautas do mangue precedido de Balinese character (re) visitado. Campinas: Editora Unicamp/ São Paulo: Imprensa Oficial do Estado de São Paulo.

OduM WE AND HeALd EJ. 1972. Trophic analyses of an estuarine mangrove community. Bull Mar Sci 22: 671-738.

OMODEI-ZORINI L, CONTINI C, JiDDAWI N, OChIEWO J, ShunUlA J AND CANNICCI S. 2004. Participatory appraisal for potential community-based mangrove management in East Africa. Ecol Manage 12: 87-102.

PALUDO D AND KLONOWSKI VS. 1999. Barra de Mamanguape PB: estudo do impacto do uso de madeira de manguezal pela população extrativista e da possibilidade de reflorestamento e manejo dos recursos madeireiros. São Paulo: MAB - UNESCO - MMA, n. 16, 54 p. (Série Cadernos da Reserva da Biosfera da mata Atlântica.).

PAssos CA AND Di BeneditTo APM. 2005. Captura comercial do caranguejo-uçá, Ucides cordatus (L., 1763), no Manguezal de Gargaú, RJ. Biotemas 18: 223-231.

PinHeIro MAA AND FisCARELli AG. 2001. Manual de apoio à fiscalização do caranguejo-uçá (Ucides cordatus). $1^{\text {a }}$ ed., Itajaí: Instituto Brasileiro do Meio Ambiente e Recursos Naturais Renováveis (IBAMA) /Centro de Pesquisa e Extensão Pesqueira das Regiões Sudeste e Sul (CEPSUL), 43 p.

RoBertson AI, ALONGI DM AND Boto KG. 1992. Food chains and carbon fluxes. In: Robertson AI and Alongi DM (Eds), Tropical Mangrove Ecosystems, American Geophysical Union Press, Washington, DC, p. 293-326. 
ROCHA MSP, MOURÃo JS, SOUTO MSW, BARBOZA RRD AND Alves RRN. 2008. O Uso dos Recursos Pesqueiros no Estuário do Rio Mamanguape, Estado da Paraíba, Brasil. Interciencia 33: 903-909.

Rist S AND DAHDOUH-GuEBAS F. 2006. Ethnosciencesa step towards the integration of scientific and traditional forms of knowledge in the management of natural resources for the future. Env Dev Sustain 8: 467-493.

SCHAEFFER-NovelLI Y. 1995. Manguezal: ecossistema entre a terra e o mar. Carib Ecol Res, p. 31-34.

TWILlEy RR, SNEDAKER RR, YÁÑEZ-ARANCIBIA SC AND MedinA A. 1996. Biodiversity and ecosystem processes in tropical estuaries: perspectives of mangrove ecosystems. In: Mooney HA, Cushman JH, Medina E, Sala OE and Schulze E-D (Eds), Functional Roles of Biodiversity: a Global Perspective, J Wiley \& Sons Ltd., New York, p. 327-370.

VAnNUCCI M. 1999. Os Manguezais e Nós. São Paulo: Edusp, 275 p.
XaVier JHA, CORDEIRO CAMM, TENÓRIO GD, DinIZ AF, JÚNIOR EPNP, ROSA RS AND ROSA IL. 2012. Fish assemblage of the Mamanguape Environmental Protection Area, NE Brazil: abundance, composition and microhabitat availability along the mangrove-reef gradient. Neotrop Ichthyol 10: 109-122.

WALTERS BB. 2004. Local management of mangrove forests: effective conservation or efficient resource exploitation? Hum Ecol 32: 177-195.

WALTERS BB. 2005. Ecological effects of small-scale cutting of Philippine mangrove forests. For Ecol Manage 206: 331-348.

WALTERs BB, RÖNNBÄCK P, KOVACS J, CRONA B, HuSSAIN S, Badola R, PrimaVERA J, BARBIER EB AND DAHDOUHGUEBAS F. 2008. Ethnobiology, socio-economics and adaptive management of mangroves: a review. Aquat Bot 89: $220-236$. 